\title{
Strategic Parameters for the Development of Potato Growing in the Regional Agro-Industial Complex
}

\author{
Popov D.* \\ Department of Farm Production Management and \\ Entrepreneurial Business in Agro-Industrial Complex \\ Voronezh State Agrarian University named after Emperor \\ Peter the Great \\ Voronezh, Russia \\ e-mail: popovdmitryvsau@gmail.com
}

Markova A.

Department of Farm Production Management and Entrepreneurial Business in Agro-Industrial Complex Voronezh State Agrarian University named after Emperor Peter the Great

Voronezh, Russia e-mail: malena1411@mail.ru

\author{
Ternovykh K. \\ Department of Farm Production Management and \\ Entrepreneurial Business in Agro-Industrial Complex \\ Voronezh State Agrarian University named after Emperor \\ Peter the Great \\ Voronezh, Russia \\ e-mail: ktern@yandex.ru
}

\author{
Leonova $\mathrm{N}$. \\ Department of Economics of Agriculture \\ Voronezh State Agrarian University named after Emperor \\ Peter the Great \\ Voronezh, Russia \\ e-mail: natalya-demcheva@yandex.ru
}

\author{
Masik A. \\ Department of Finance and Credit \\ Voronezh State Agrarian University named after Emperor Peter the Great \\ Voronezh, Russia \\ e-mail: masikav@list.ru
}

\begin{abstract}
The article substantiates the need of creation a potato cluster in the Voronezh region for sustainable development of the potato industry. The strategic parameters of the development of the potato industry in the region are determined in a multivariate performance. The results of applying the economic-mathematical model to optimize the sectoral structure of the agricultural sector of the region are estimated. Bringing the sectoral structure of production in the region to the optimal will increase potato production by 40 centners from 100 hectares of arable land, as well as increase profitability to $11.5 \%$, revenue per 100 hectares of farmland by 401 thousand rubles, and profit per 100 hectares of farmland by 57 thousand rubles.
\end{abstract}

Keywords - potato growing; strategic planning; economicmathematical model; potato cluster.

\section{INTRODUCTION}

Potato is an important food product because it allows satisfying the needs of both its consumers and producers. The consumers of this product are attracted by various taste characteristics, a cheap price, as well as many dishes that can be prepared from potatoes. We can also get potato chips from potatoes, French fried potatoes, potato flakes, potato starch and even alcohol, which causes a certain interest from processing enterprises. Producers of potato value this product for its high crop productivity and, as a result, the possibility of obtaining high income from potato production.

However, a certain tendency has developed in the potato market in Russia. A significant share in the structure of potato production is occupied by household plot, which is associated with a difficult situation in the 1990s, when Russians grew potatoes on their own. This factor has a significant impact on the potato market in Russia in general and the Voronezh region in particular. In our opinion, the predominance in the structure of production of household plots slows down the sustainable development of the potato cluster in the Voronezh region, as it creates the conditions for the occurrence of overproduction of potatoes and strengthening barriers to entry into the potato market.

Analysis of statistics of recent years shows that the main volume of seed potatoes of higher reproductions is used for planting in agricultural enterprise and in peasant farms. Households' plots extremely rarely update their own seed stock, and as a rule, they have traditionally been using seeds of their own production for many years. For this reason, in farms of all categories, the seed potatoes are represented by perennial, often unknown reproductions with low yield characteristics. The system of providing household plots with highly productive certified seed material for strain renovation and strain changing 
in most regions has not established which is due, first of all, to extremely insufficient volumes of seed production of higher reproductions.

\section{THE NEED OF CREATION OF POTATO CLUSTER}

The seed potatoes, delivered from the Netherlands, do not be affected by sanctions, therefore, the Government of the Russian Federation is considering the possibility of concentrating financial resources on import substitution and seed production. However, the problem is compounded by increasing competitive pressure from foreign suppliers of seed potatoes to the domestic market, which forces domestic agricultural enterprises and peasant farms to buy them on the basis of economic benefits, and the population to buy imported potatoes. The country cannot feel safe enough because of its dependence on seed supplies from the European Union. Therefore, it is effectually to restore seed production in potato growing and renewal of public administration in this sub-sector.

The modern development of innovative technologies in the potato growing of agricultural enterprises and peasant farms requires a detailed analysis and scientific reflection in order to identify patterns, motives and incentives for a positive process that could be used to bring other agricultural industries and areas of specialization to the trajectory of sustainable development. In addition, a forecast for the long-term development of potato growing is required. After all, the market is crowded and along with this, the competitive struggle of regional Agro-industrial complexes for a greater or lesser presence on it is strengthen.

To carry out scientific and production programs at a high organizational, material and technological level in the region, the formation and development of a potato cluster is necessary.

III. SUBSTANTIATION OF THE ECONOMIC-MATHEMATICAL MODEL FOR PLANNING POTATO PRODUCTION IN THE REGION

One of the problems of rational and effective organization of land tenure is the necessity of ensuring such an alternation of cultivated crops that would meet scientifically substantiated norms of the optimal structure of sown areas. Nowadays, economics knows two different approaches to solving the problem of bringing the structure of the planted areas of the enterprise to the optimal. The idea of the first approach involves optimizing the structure of crops by abidance the scientifically substantiated confines of saturation of crop rotation with various crops. The second approach is deeper, based on the establishment of the optimal structure of cultivated areas by correlating them to current or planned crop rotations due to the determining of cultivation areas of various crops that can be located on specific crop rotation fields. For accomplishment this article, the second approach was used, carried out in four stages, including:

1) The purpose of building an economic-mathematical model;

2) Preparation of initial information;

3) Building of an economic-mathematical model;

4) The solution of the economic-mathematical model and analysis of the results.
Purpose. The presence of certain resources on the agricultural market of the Voronezh region suggests the need of searching for a specific combination of sown areas that would fully support the production of products at the proper level in household plots, created the conditions for obtaining the largest amount of profit in agricultural enterprises and peasant farms, thereat considering in the model agricultural requirements, contractual obligations for the sale of products, animal feed requirements, etc.

Preparation of initial information. In the Voronezh region there are 2299 thousand hectares of arable land from farm enterprises, 747 thousand hectares from peasant farms, and 135 thousand hectares from personal subsidiary farms. In the course of marketing activities, agricultural enterprises concluded contracts for the sale of 1767 thousand tons of winter wheat, 536 thousand tons of barley, 683 thousand tons of corn, 61 thousand tons of peas, 3996 thousand tons of sugar beets , 698 thousand tons of sunflower, 306 thousand tons of potatoes, 14 thousand tons of field vegetables, 12 thousand tons of greenhouse vegetables, 546 thousand tons of milk, 27 thousand tons of cattle growth, 203 thousand tons of growth of pigs, 75 tons of goat milk, 134 tons of growth of sheep and goats, 9 tons of sheep wool 2 thousand tons of growth of birds and 446,207 thousand pieces chicken eggs. Peasant farms also concluded contracts for the sale of 594 thousand tons of winter wheat, 144 thousand tons of spring wheat, 18 thousand tons of peas, 278 thousand tons of barley, 11 thousand tons of soybeans, 683 thousand tons of sugar beets, 196 thousand tons of sunflower, 25 thousand tons of potatoes, 39 thousand tons of field vegetables, 50 tons of greenhouse vegetables, 34 thousand tons of milk, 1 thousand tons of cattle growth, 209 tons of growth of pigs, 948 tons of growth of sheep and goats, 90 tons of sheep wool, 480 tons of growth of birds and 4714 thousand pieces chicken eggs. In household plots, retention of production volumes is expected, include of 747 thousand tons of potatoes, 233 thousand tons of field vegetables, 12 thousand tons of cucurbits, 931 tons of milk, 18 thousand tons of cattle and poultry, and also 339.000 thousand pieces chicken eggs.

Market analysis of agricultural products, as well as various conditions of the agreements concluded, establishes a specific set of crops for cultivation. It is planned to cultivate crops such as winter wheat, barley, corn for grain, peas, sugar beets, sunflowers, potatoes, field vegetables, greenhouse vegetables, corn for silage and green fodder, annual grass for hay, haylage and green, winter crops for green fodder, as well as perennial grasses for hay, haylage and green fodder. It is also necessary to make allowance that there are hayfields in the region in the amount of: agricultural enterprises - 81 thousand hectares, peasant farms -23 thousand hectares. In addition, the yield of various crops should be planned at the level actually achieved in the region over the past four years for all categories of farms. Costs of material and monetary funds per 1 hectare of sowing are determined on the basis of flow process chart calculated and used at the leading enterprises of the region for crops.

Potato yields on peasant farms are planned at the level of 180 centner/hectare, and the yield of field vegetables is 230.7 centner/hectare. Production of various types of products is planned. The planning of the output of by-products is carried out by requirement of the enterprise. Agricultural enterprises 
and peasant farms will use by-products of winter wheat, barley, peas, soybeans and sugar beets. For winter wheat, barley and peas, the enterprise will receive straw, for sugar beets - tops.

In total, considering the insurance fund, 2.5 centner of winter wheat seeds and 2.97 centner of barley per 1 hectare of sowing will be required. Also, 1 hectares of planting will require 27.5 centner of potatoes. For other crops, it is planning to use purchased seeds.

Crop products are distributed based on yield planning and identifying various channels for its consumption. It is necessary to consider the percentage of waste for various types of products, as well as to plan the need for seeds of winter wheat, barley and potatoes.

Commodity products of the region are represented by winter wheat, barley, peas, corn for grain, soybeans, sugar beets, sunflowers, potatoes, field vegetables, and greenhouse vegetables. It is determined by subtracting from the planned yield the percentage of waste, seed requirements and animal feed requirements, if any exist.

Maize for silage and green fodder, perennial and annual grasses, winter crops for green fodder, as well as by-products of production cereals and legumes, soybeans and sugar beets will go to livestock feed. It is also planned to use the hayfields available at the enterprise.

The physiological requirements of animals during feeding allow changing the proportions of certain types of fodder in the diet. Therefore, there is a need to form nutritionally balanced diets for feeding farm animals and considering the economic feasibility of using each type of feed in the diet.

The green forage chain provides animals with a continuous supply of feed of their own production during the summer period, so it is a fairly important element in the supply of livestock feed.

When organizing a science-based crop rotation, there is a need to determine the confines of inclusion of various crops or their groups in the structure of sown areas. For agricultural enterprises of the Central Black Earth economic region, the recommended specific gravity of grain crops in the structure of sown areas should be from 40 to $60 \%$. The maximum proportion of sunflower should not exceed $12.5 \%$, peas $10 \%$. The confines of the inclusion of other industrial crops in the crop rotation are established by the specific conditions of the enterprise for their cultivation. More often in agricultural enterprises and peasant farms, follow crop rotation is used:

- fallow and other forecrops for winter cereals;

- winter cereals;

- $\quad$ tilled crops;

- $\quad$ spring cereals;

- forecrops for winter cereals;

- winter cereals;

- tilled crops.
Based on the level of cattle productivity achieved on the farm, the structure of feeding diets, developed taking into account the economic feasibility of including these feeds in the diet, the need for feed per one structural head is determined.

Market conditions and terms of contracts with customers form a certain level of prices for the sale of manufactured products. In agricultural enterprises, the products will be sold at the following prices: winter wheat -890 rubles/centner, barley -908 rubles/centner, peas -1180 rubles/centner, corn for grain - 804 rubles/centner, soybeans - 2382 rubles/centner, sugar beets -277 rubles/centner, sunflower - 1992 rubles/centner, potatoes 900 rubles/centner, field vegetables - 850 rubles/centner, greenhouse vegetables - 6660 rubles/centner, milk - 2521 rubles/centner, cattle meat - 13025 rubles/centner, pigs meat- 9449 rubles/centner, goat milk - 2974 rubles/centner, meat of sheep and goats - 9020 rubles/centner, sheep wool - 2194 rubles/centner, poultry meat - 10659 rubles/centner, eggs - 3977 rubles/1000 pcs. The following selling prices were formed at the peasant farms: winter wheat 890 rubles/centner, barley - 908 rubles/centner, peas - 1180 rubles/centner, corn for grain -753 rubles/centner, soybeans -2 468 rubles/centner, sugar beets - 248 rubles/centner, sunflower 2091 rubles/centner, potatoes 940 rubles/centner, field vegetables -768 rubles/centner, greenhouse vegetables -6660 rubles/centner, milk - 1517 rubles/centner, cattle meat- 9757 rubles/centner, pigs meat -8252 rubles/centner, meat of sheep and goats - 8958 rubles/centner, sheep wool 2596 rubles/centner, poultry meat - 18030 rubles/centner, eggs - 10615 rubles/1000 pcs.

\section{BUILDING AN ECONOMIC-MATHEMATICAL MODEL}

After substantiating the input information, we should proceed to the construction of an economic-mathematical model.

The system of variables of this economic and mathematical problem is represented by the main and auxiliary variables.

The main variables are the acreage of agricultural crops and the livestock of agricultural animals. The auxiliary variables are material and monetary costs.

All conditions of the problem are written in the form of linear equations and inequalities (constraints). The structural record of the economic-mathematical model for optimizing the sectoral structure of agricultural enterprise in the region has the following form

Find the objective function:

$$
Z_{\max }=\sum_{\mathrm{j}=1}^{80} \mathrm{t}_{\mathrm{j}} \mathrm{X}_{\mathrm{j}}-\mathrm{X}_{105},
$$

where $t_{j}$ - the planned revenue from 1 hectare of the $j$-th crop, from 1 head of the $j$-th species of animals, from 1 centner of the $\mathrm{j}$-th type of production.

Under the following restrictions:

1. On the use of land and labor in agricultural enterprises:

$\sum_{j=1}^{28} X_{j} \leq B \_o r g_{i}, \quad$ for $(\mathrm{i}=1, \ldots, 3)$

where $X_{j}$ - the sown area of the $j$-th crop or the $j$-th type of agricultural land; 
B_org $\mathrm{i}_{\mathrm{i}}-$ the area of land available in the organization.

2. For the conservation of cattle and other animals in agricultural enterprises at a constant level:

$X_{j}=G_{\_}$org $_{i}$, for $(\mathrm{i}=4, \ldots, 9)$

where $X_{j}$ - the number of cattle;

$\mathrm{G}_{-}$org $_{\mathrm{i}}-$ livestock of the $\mathrm{i}$-th species.

3. On the implementation of agrotechnical requirements for the structure of crop rotation in agricultural enterprises:

$\left\{\begin{array}{l}\sum_{j=1}^{26} \geq Q_{-} \text {org }_{i}^{\min } \\ \sum_{j=1}^{26} \leq Q_{-} \text {org }_{i}^{\text {max }}\end{array}\right.$, for $(\mathrm{i}=10, \ldots, 23)$

where Q_org ${ }_{i}^{\text {max }}$ and Q_org ${ }_{i}^{\text {min }}$ - the maximum and minimum crop sowing confines, respectively.

4. To provide winter crops with forecrops in agricultural enterprises:

$$
\sum_{j=1}^{2} X_{j}-\sum_{j=3}^{26} \alpha \_\operatorname{org}_{j} X_{j}^{P} \leq 0 \text {, for }(\mathrm{i}=24)
$$

where $X_{j}^{P}$ - the sown area of the $j$-th agricultural crop, which may be the forecrop for winter crops;

$\alpha_{j}$ - the coefficient of the possible use of crops of the $j$-th agricultural crop as a forecrop for winter crops.

5. For the fulfillment of contractual obligations for the sale of products in agricultural enterprises:

$\sum_{j=1}^{41} r_{-}$org $g_{i j} X_{j} \geq R \_o r g_{i}$, for $(\mathrm{i}=25, \ldots, 43)$

where $r_{-}$org $_{i j}$ - the output of the i-th species per 1 hectares of sowing of the $j$-th agricultural crop or 1 structural head of the $j$ th livestock species;

$\mathrm{R}$ org $\mathrm{i}_{\mathrm{i}}$ - the minimum required volume of production of commercial yield of the i-th type under contractual obligations.

6. To meet the needs of animals in feed in agricultural enterprises:

$$
\sum_{j=1}^{28} d \_o r g_{i j} X_{j}+\sum_{j=29}^{35} p_{-} \text {org } g_{i j} X_{j} \geq \sum_{j=36}^{41} k_{-} \text {org } X_{i} X_{j},
$$

for $(i=44, \ldots, 64)$

where d_org $\mathrm{ij}_{\mathrm{ij}}$ - the output of the i-th type of feed from 1 ha of the $\mathrm{j}$-th crop;

p_org $\mathrm{ij}_{\mathrm{j}}$ - nutritional value of the $\mathrm{j}$-th type of feed, which we acquire or produce in animal husbandry;

$\mathrm{k} \_{ } \mathrm{org}_{\mathrm{i}}-$ the need for animals in the $\mathrm{i}$-th form of feed.

7. On the use of land and labor resources in peasant farms:

$\sum_{j=42}^{69} X_{j} \leq B_{-}$farm $_{i}, \quad$ for $(\mathrm{i}=65, \ldots, 67)$

where $X_{j}$ - the sown area of the $j$-th crop or the $j$-th type of agricultural land;

B_farm ${ }_{i}$ - land area available on farms.

8. For the conservation of cattle and other animals in peasant farms at a constant level:

$X_{j}=G_{-}$farm $_{i}, \quad$ for $(\mathrm{i}=68, \ldots, 71)$ where $X_{j}$ - the number of cattle;

$G_{-}$farm $_{i}$ - livestock of the $i-t h$ species.

9. For the implementation of agricultural requirements for the structure of crop rotation in peasant farms:

$$
\left\{\begin{array}{l}
\sum_{j=42}^{67} \geq Q_{-} \text {farm }_{i}^{\text {min }} \\
\sum_{j=42}^{67} \leq Q_{-} \text {farm }_{i}^{\text {max }}
\end{array} \text {, for }(\mathrm{i}=72, \ldots, 85)\right.
$$

where Q_farm ${ }_{\mathrm{i}}^{\max }$ and Q_farm ${ }_{\mathrm{i}}^{\text {min }}$ - the maximum and minimum crop sowing confines, respectively.

10. To provide winter crops with forecrops in peasant farms:

$$
\sum_{j=42}^{43} X_{j}-\sum_{j=44}^{67} \alpha_{-} \text {farm }_{j} X_{j}{ }^{P} \leq 0 \text {, for }(\mathrm{i}=86)
$$

where $\mathrm{X}_{\mathrm{j}}^{\mathrm{P}}$ - the sown area of the $\mathrm{j}$-th agricultural crop, which may be the forecrop for winter crops;

$\alpha \_$farm $_{j}-$ coefficient of possible use of crops of the $j$-th agricultural crop as a forecrop for winter crops.

11. On the fulfillment of contractual obligations for the sale of products in peasant farms:

$\sum_{j=42}^{80} r_{\_}$farm $_{i j} X_{j} \geq R_{\_}$farm $_{i}$, for $(\mathrm{i}=87, \ldots, 104)$

where $r_{-}$farm $_{\mathrm{ij}}$ - the output of the $\mathrm{i}$-th species per 1 ha of sowing of the $\mathrm{j}$-th agricultural crop or 1 structural head of the $\mathrm{j}$-th livestock species;

R_farm ${ }_{i}$ - the minimum required volume of production of commercial yield of the i-th type under contractual obligations.

12. To meet the needs of animals in feed in peasant farms: $\sum_{j=42}^{69} d_{-}$farm $_{i j} X_{j}+\sum_{j=70}^{76} p_{-}$farm $_{i j} X_{j} \geq \sum_{j=77}^{80} k_{-}$farm $_{i} X_{j}$, for $(\mathrm{i}=105, \ldots, 125)$

where d_farm $\mathrm{ij}_{\mathrm{j}}$ is the output of the $\mathrm{i}$-th type of feed from 1 ha of the $\mathrm{j}$-th crop;

$p_{-}$farm $_{i j}-$ nutritional value of the $j$-th type of feed, which we acquire or produce in animal husbandry;

$\mathrm{k} \_$farm $_{\mathrm{i}}$ - the need of animals for the $\mathrm{i}$-th form of food.

13. On the use of land and labor in household plots:

$\sum_{j=81}^{92} X_{j} \leq B \_$pers $s_{i}$, for $(\mathrm{i}=126, \ldots, 128)$

where $\mathrm{X}_{\mathrm{j}}$ is the sown area of the $\mathrm{j}$-th crop or the $\mathrm{j}$-th type of agricultural land;

B_pers $\mathrm{i}^{-}$area of land available to the population.

14. For the conservation of cattle and other animals in household plots at a constant level:

$X_{j}=G_{\_}$pers $_{i}, \quad$ for $(\mathrm{i}=129, \ldots, 132)$

where $\mathrm{X}_{\mathrm{j}}$ - livestock;

G_pers ${ }_{i}$ - livestock of the $\mathrm{i}$-th species.

15. On the implementation of agrotechnical requirements for the structure of crop rotation in household plots: 


$$
\left\{\begin{array}{l}
\sum_{j=81}^{90} \geq Q_{\text {_pers }}{ }_{i}^{\text {min }} \\
\sum_{j=81}^{90} \leq Q_{\text {_pers }}{ }^{\text {max }}
\end{array} \text {, for }(\mathrm{i}=133, \ldots, 138)\right.
$$

where Q_pers ${ }_{\mathrm{i}}^{\text {max }}$ and Q_pers ${ }_{\mathrm{i}}^{\text {min }}$ - the maximum and minimum crop sowing confines, respectively.

16. To maintain production volumes in household plots:

$\sum_{j=81}^{104} r \_$pers $s_{i j} X_{j} \geq R \_$pers $s_{i}$, for $(\mathrm{i}=139, \ldots, 145)$

where $r_{-}$pers $s_{i j}$ - the output of the $i$-th species per 1 ha of sowing of the $j$-th agricultural crop or 1 structural head of the $j$-th livestock species;

$\mathrm{R} \_$pers $\mathrm{s}_{\mathrm{i}}$ - the minimum required volume of production of the $\mathrm{i}$-th to maintain production volumes.

17. To meet the needs of animals in feed for household plots:

$$
\begin{aligned}
& \sum_{j=84}^{92} d_{\_} \text {pers }_{i j} X_{j}+\sum_{j=93}^{100} p_{\_} \text {pers }_{i j} X_{j} \geq \sum_{j=101}^{104} k_{-} \text {pers }_{i} X_{j}, \\
& \text { for }(\mathrm{i}=146, \ldots, 164)
\end{aligned}
$$

where d_pers $\mathrm{s}_{\mathrm{ij}}$ - the output of the i-th type of feed from 1 ha of the $\mathrm{j}$-th crop;

p_pers ${ }_{i j}$ - nutritional value of the $\mathrm{j}$-th type of feed, which we acquire or produce in animal husbandry;

$\mathrm{k} \_$pers $\mathrm{i}_{\mathrm{i}}$ - the need for animals in the $\mathrm{i}$-th form of food.

18. By definition of material and monetary costs in agricultural enterprises and peasant farms:

$\sum_{j=1}^{28} z_{-}$org $X_{j} X_{j}+\sum_{j=29}^{35} c_{-}$org $X_{j} X_{j}+\sum_{j=36}^{41} v_{-}$org $_{j} X_{j}+$ $\sum_{j=42}^{69} z_{-}$farm $_{j} X_{j}+\sum_{j=70}^{76} c_{-}$farm $_{j} X_{j}+\sum_{j=77}^{80} v_{-}$farm $_{j} X_{j}=$ $X_{105}$

for $(i=165)$

where $\mathrm{z}_{-}$org $\mathrm{j}_{\mathrm{j}}$ - the cost per 1 ha of sowing the $\mathrm{j}$-th crop in agricultural enterprises;

c_org ${ }_{j}-$ value of the purchased $j$-th type of feed in agricultural enterprises;

v_org ${ }_{j}-$ costs for 1 structural head of the $\mathrm{j}$-th animal species in agricultural enterprises;

$z_{-}$farm $_{j}-$ costs per 1 ha of sowing the $j$-th crop in peasant farms;

c_farm ${ }_{j}-$ the cost of the purchased $j$-th type of feed in peasant farms;

$v_{-}$farm ${ }_{j}-$ costs for 1 structural head of the $j$-th animal species in peasant farms.

19. By the condition of non-negativity of the variables:

$X_{j} \geq 0$, where $_{\mathrm{j}=1,2, \ldots 105}$.

\section{RESULTS}

The implementation of the developed economicmathematical model for optimizing the structure of sown areas is carried out using the add-in "Solver" from the menu item "Data" Microsoft Excel 2007.
Based on the solution of the economic-mathematical model, we have obtained the following values of indicators which presented in Table 1.

TABLE I. OPTIONS FOR SOLVING THE ECONOMIC-MATHEMATICAL MODEL

\begin{tabular}{|l|r|r|r|r|}
\hline \multirow{2}{*}{ Indicators } & \multirow{2}{*}{ Fact } & \multicolumn{3}{|c|}{ Options } \\
\cline { 3 - 5 } & $\mathbf{2 0 1 8}$ & \multicolumn{1}{c|}{$\boldsymbol{A}$} & $\boldsymbol{B}$ & \multicolumn{1}{c|}{$\boldsymbol{C}$} \\
\hline $\begin{array}{l}\text { Produced on 100 hectares of arable land, } \\
\text { centner }\end{array}$ & & & & \\
\hline grains & 1283 & 1582 & 1587 & 1576 \\
\hline sugar beet & 1471 & 2210 & 2220 & 2202 \\
\hline sunflower seeds & 281 & 325 & 327 & 324 \\
\hline soybeans & 55 & 74 & 74 & 73 \\
\hline potatoes & 252 & 263 & 293 & 270 \\
\hline field vegetables & 90 & 119 & 120 & 119 \\
\hline pig meat & 69 & 66 & 67 & 66 \\
\hline Produced per 100 hectares of farmland & & & & \\
\hline milk, centner & 159 & 189 & 189 & 189 \\
\hline cattle in live weight, centner & 8 & 8 & 8 & 8 \\
\hline sheep meat, centner & 0.3 & 1 & 1 & 1 \\
\hline sheep wool, centner & 0.03 & 0.03 & 0.03 & 0.03 \\
\hline commercial yield, thousand rubles & 3438 & 3817 & 3839 & 3823 \\
\hline profit, thousand rubles & 337 & 384 & 394 & 384 \\
\hline Produced per 100 hectares of grain crops & & & & \\
\hline eggs, thousand pcs. & 55 & 64 & 64 & 64 \\
\hline poltury meat, centner & 2 & 4 & 4 & 4 \\
\hline Profitability level, \% & 10.9 & 11.2 & 11.5 & 11.2 \\
\hline
\end{tabular}

The first variant of the optimal sectoral structure of production involves the optimization of the sectoral structure of production in agricultural enterprises, peasant farms and household plots, as well as using of balanced rations. If implementing this option, revenue per 100 hectares of farmland will be 3817 thousand rubles, and profit -384 thousand rubles. The profitability level of this option will be $11.2 \%$.

The second option involves increasing potato yields. This option allows getting 3839 thousand rubles. revenue per 100 hectares of farmland, and profit -394 thousand rubles. The profitability level of this option is $11.5 \%$.

The third option involves increasing the area under cultivation of potatoes while maintaining the current level of productivity. The implementation of this option involves the receipt of revenue per 100 hectares of farmland in the amount of 3823 thousand rubles, while the profit per 100 hectares of farmland will be 384 thousand rubles. The profitability level of this option will be $11.2 \%$ in the whole region.

\section{CONCLUSIONS}

The analysis of the options for optimizing the strategic parameters for the development of potato growing in the regional Agro-industrial complex indicates that the second option is the most preferable one, when the profitability level reaches $11.5 \%$, revenue per 100 hectares of farmland will be 3839 thousand rubles, and the profit per 100 hectares of farmland will be 394 thousand rubles.

The application of this option will also allow increasing potato production by 40 centner from 100 hectares of arable land. It should be noted that for the sustainable development of potato growing in the Voronezh region, an increase in potato 
production should take place in agricultural enterprises and peasant farms.

The results and the applied methodology can be used to substantiate the strategic parameters for the development of the potato industry in other regions.

\section{References}

[1] S.A. Kameneva, I.P. Boriskina "Mathematical modeling in economics", Bull. of the Volga Univer. V.N. Tatishcheva, vol. 2, no. 2, pp. 25-29, 2016.

[2] Y.A. Ponkratova, "Economic and Mathematical Modeling of AgroIndustrial Enterprises", T-Comm - Telecommunicat. and Transp., no. S2, pp. 192-193, 2009.

[3] L.N. Devyatkina, "Potato Production: Global and National Discourses", Vest. NGIII, vol. 5, no. 84, pp. 122-134, 2018

[4] L.N. Devyatkina, A.P.Sakov, E.N. Ignateva,V.P. Polozova, "Scenarious forecasting of potato development considering of the food security requirements of the region”, Moscow Econ. J., no. 3, pp. 2-4, 2016.

[5] I.V. Kislova, 'Potato Production Efficiency in the Russian Federation', Volga Niva, vol. 1, no. 42, pp. 105-110, 2017.

[6] N.A. Smirnov, G.V. Gruzdev, "Optimization of the production and sale of potato products", Vest. NGIIE, vol. 7, no. 74, pp. 100-109, 2017.

[7] N.A. Smirnov, A.A. Smirnova, N.T. Savrukov, "Cluster approach to increasing the economic and resource potential of potato growing",
Azimuth of Sci. Res.: Econ. and Manag.t, vol. 8, no. 1(26), pp. 294-297, 2019.

[8] B.M. Shundalov, "Economic Efficiency of Production and Sale of Potatoes", Bull. of the Belarusian State Agricult. Acad., no. 1, pp. 5-8, 2017.

[9] N.M Filimonova, T.N. Kashitsyna, E.S. Lovkova, "Development of measures for the development strategy of the potato industry in the Vladimir region", Manag. Issues, vol. 5, no. 42, pp. 52-61, 2016.

[10] B.M. Albogachieva, "Economic efficiency of potato production in various categories of farms", Reg. probl. of econ. transformat., no. 3, pp. 91-98, 2010

[11] A.V. Korshunov, E.A. Simakov, Y.N. Lysenko et al., "Actual problems and priority directions of development of potato growing", Achievements of sci. and technol. of agro-industr. complex, vol. 32, no. 3, pp. 12-20, 2018.

[12] L.P. Silaeva, "Commodity flows in the potato market", Bull. of the Kursk State Agricult. Acad., no. 1, pp. 6-11, 2016.

[13] N. Ivanov, A. Khasanov, "Application of economic and mathematical models to optimize the use of sown areas in the agricultural sector of the Central Federal District”, Int. Agricult. J., no. 1, pp. 47-50, 2015.

[14] N.V. Byshov, S.N. Borychev, A.A. Simdyankin et al., "A Modern Look at Potato Production", Political-acad. online electr. Sci. J. of the Kuban State Agricult. Univer., no. 128, pp. 146-153, 2017.

[15] N.A. Smirnov, "The Importance of Potato Production in the Agrarian Economy and the Ensuring Food Independence of the Region", Azimuth of Sci. Res.: Econ. and Manag., vol. 5, no. 3(16), pp. 183-188, 2016. 